\title{
How Does COVID-19 Pandemic Affect Rice Yield? Lessons from, Southeast Nigeria
}

\author{
Esiobu, Nnaemaka Success \\ Doctoral Researcher \\ Department of Agricultural Economics, Extension and Rural Development, \\ Imo State University, Owerri, Nigeria
}

\begin{abstract}
At the global level and particularly across sub-Saharan African (SSA), while rice farmers are still battling the negative impact of climate change and greenhouse gases (GHGs) emissions, the COVID-19 pandemic has brought a new risk that not only threatens farmers livelihoods but also the most important global food security crop "Rice". Every farming season in Nigeria, rice farmers face risks such as low rainfall, price volatility, methane emissions, rising debts and poor government policies. But the present risks from the COVID-19 pandemic are putting new challenges in front of rice value-chain that is already under serious threat. Additionally, the growing demand for rice across SSA and particularly in Nigeria exceeds supply, resulting in a rice deficit. To overcome this challenge, rice yield should be increased particularly now there is a new threat for farmers. As a matter of urgency, farmers must respond to this new threat (COVID-19) by choosing measures that increase their yield. Incidentally, empirical studies that documented the effect of COVID-19 pandemic on rice yield cannot be found as at the time of this study. These create emptiness in research and make it extremely difficult if not impossible for the government/interest group to know the method they can use in helping farmers mitigate the negative effect of COVID-19 pandemic in rice production. It was against this backdrop that this study was systematically undertaken. The study was meticulously guided five (5) objectives. The survey was conducted from March through July 2020. A cross-sectional data was elicited from 504 rice farmers selected across Southeast Nigeria. Data collected were analyzed using descriptive statistical tools such as means, flow-chart, percentage and likert scaletype. Mean age was 45.00 years. Greater proportions $(61.30 \%)$ were male. A very salient finding was that COVID19 pandemic is disrupting activities of rice value-chain like harvesting of 2019/2020 season's produce that was ongoing and land preparations and planting for 2020/2021 season $(\overline{\mathrm{x}}=\geq 3.11)$. Result show that the non-availability of labour is interrupting planting, harvesting and distribution activities of rice $(\overline{\mathrm{x}}=\geq 3.32)$. There are disruptions in purchase of inputs because of restrictions $(\bar{x}=\geq 3.12)$. Findings also developed incisive conceptual framework showing the effect of COVID-19 pandemic in rice farming. Result also shows that extension visits to farmers have been seriously limited $(85.32 \%$ had no visit) due restrictions. With this present threat, Nigeria are likely to experience a reversal in the development gains already achieved and will be unlikely to achieve the 2030 Sustainable Development Goals and the aspirations of African Agenda 2063. The study therefore identified the need for governments at all levels in the country to design a sustainable policy in such a way that farmers should have access to affordable farm credit as well as subsidized agricultural inputs in order to increase their ability and flexibility to change in production strategies in response to COVID-19 pandemic.

Keywords: COVID-19 Pandemic; Rice; Conceptual Framework; Socio-economic Variables; Awareness; Source of Information; Precautionary Measure; Perceived effect of COVID-19 Pandemic; Barriers; Recommendations; Southeast Nigeria and sub-Saharan African (SSA),
\end{abstract}

DOI: $10.7176 / \mathrm{JBAH} / 10-15-06$

Publication date:August $31^{\text {st }} 2020$

\section{INTRODUCTION}

The first human cases of COVID-19, the disease caused by the novel coronavirus causing COVID-19, subsequently named SARS-CoV-2 were first reported by officials in Wuhan City, China, in December 2019 [1]. Retrospective investigations by Chinese authorities have identified human cases with onset of symptoms in early December 2019 [2]. While some of the earliest known cases had a link to a wholesale food market in Wuhan, some did not. Many of the initial patients were stall owners, market employees, or regular visitors to this market. Environmental samples taken from this market in December 2019 tested positive for SARS-CoV-2, further suggesting that the market in Wuhan City was the source of this outbreak or played a role in the initial amplification of the outbreak [3]. The market was closed on 1 January 2020. The World Health Organization declared COVID19 a global pandemic on 11 March 2020 [28]. Since 31 December 2019 and as of 08 August 2020, 19,680,042 cases of COVID-19 (under the applied case definitions and testing strategies in the affected countries) have been reported, including $\mathbf{7 2 7 , 7 7 7}$ deaths globally and 992,710 cases across sub-Saharan African (SSA) [1].

The first confirmed case in Nigeria was announced on 27 February 2020, when an Italian citizen in Lagos tested positive for the virus [5]. Specifically, across sub-Saharan African (SSA) and as at 08 August 2020 the five countries reporting most cases are South Africa $(553,188)$, Egypt $(95,314)$, Nigeria $(46,140)$, Ghana 
(41,003) and Algeria (34,693) [4]. The African continent is already grappling with food security challenges. Locust swarms in the Horn of Africa, regional insecurity and conflict, climate-change-related droughts and flooding are destroying crops and the livelihoods of millions of African smallholder farmers [31]. Furthermore, the COVID-19 pandemic potentially undermines the capacity of both short-term production and distribution. With its far-reaching geographical spread, the pandemic is projected to have devastating effects on the global economy, as attested by the projection of the International Monetary Fund (IMF) in April 2020 that the world economy would contract sharply by $3 \%$, and that the economy of sub-Saharan Africa would contract by $1.60 \%$ in 2020 [24]. Furthermore, Economic Commission for Africa (ECA) has projected that, in a worst-case scenario, economic activity for Africa as a whole would contract by $2.60 \%$, with negative impacts on the employment rate, and that estimated that four out of five businesses in Africa would be significantly affected by the COVID-19 pandemic [25]. The African Development Bank (AfDB) predicted an economic contraction for the continent of $3.40 \%[26]$.

In Nigeria, the pandemic has already precipitated rice crises by disrupting rice value-chain system, thereby posing a great threat to actors of the rice value chain system livelihoods as well as national food and nutritional security. The Nigerian government had initiated an early coordinated response to minimize the impact by developing strategies to facilitate free movement of rice seedlings and agricultural inputs exempted from lockdown. Although agricultural value chain area exempted from lockdown, limits on the mobility of farmhands are contributing to labour shortages for rice sectors as it is characterised by periods of peak seasonal labour demand and labour-intensive production. Additionally, harvesting and distribution season is imminent in rice values-chain, and a shortage of labour is leading to production losses and shortages in the market. In Nigeria, this comes on one of the top existing difficulties in sourcing seasonal and harvesting labour for rice.

Therefore, rice (Oryza spp.), which is the second-largest most consumed cereal (after wheat), shapes the lives of millions of households globally [6]. More than half of the worlds' population depends on rice for about $80 \%$ of its food calorie requirements [7]. It has become a staple food in Nigeria such that every household, both the rich and the poor, consumes a great quantity [8]. A combination of various factors seems to have triggered the structural increase in rice consumption over the years with consumption broadening across all socioeconomic classes, including the poor [9]. The rising demand could be as a result of increasing population growth and income level coupled with the ease of its preparation and storage [8]. In Nigeria, while rice farmers are still battling the negative impact of climate change and greenhouse gases (GHGs) emissions, the COVID-19 pandemic has brought a new risk that not only threatens farmers livelihoods but also the most important global food security crop "Rice". Every farming season in Nigeria, rice farmers face risks such as low rainfall, price volatility, methane emissions, rising debts and poor government policies. But the present risks from the COVID-19 pandemic are putting new challenges in front of rice value-chain that is already under serious threat. Additionally, the growing demand for rice across s sub-Saharan African (SSA) and particularly in Nigeria exceeds supply, resulting in a rice deficit. Currently, due to the present government objective on diversification of the economy, rice is grown in almost 36 states in Nigeria including Federal Capital Territory (FCT) under diverse production systems and agroclimatic conditions $[8]$.

To the farmers across Southeast Nigeria, the effect of COVID-19 pandemic on agriculture, especially rice production, is very important. This is because the majority of the inhabitants depend on rice production for their livelihood. Rice is highly susceptible to seasonal shock, greenhouse gases and climate vagaries because of its sensitivity to changing climatic conditions [8].The COVID-19 pandemic is already affecting the livelihoods of rural communities across Southeast Nigeria, which is predominately rice-based, and increasing their vulnerability as well. The increasing variability, greenhouse gases, intensity and erratic nature of rainfall, rising incidence of flood and soil erosion, and serious decline in agricultural yields are among the obvious climate change hazards ravaging communities across Southeast Nigeria $[8,10,14]$. To overcome this challenge, rice production/yield should be increased particularly now there is new threat for farmers. As a matter of urgency, farmers must respond to this new threat (COVID-19) by choosing measures that increase their yield.

Incidentally, empirical studies that documented the effect of COVID-19 pandemic on rice yield cannot be found as at the time of this study. These create emptiness in research and make it extremely difficult if not impossible for the government/interest group to know the method they can use in helping farmers mitigate the negative impact of COVID-19 pandemic in rice production. Southeast Nigeria has an estimated land mass of $32,610 \mathrm{~km}^{2}$ and a population of 22,583,076 persons [11,12]. On average, the poverty level in South East is about $43.00 \%$ which means that about $43.00 \%$ of South East citizens are classified as very poor [16]. Also it is estimated that the number of people living below the poverty line in developing countries of which Nigeria is included will rise by 29 million [27]. Therefore, this demonstrates how vulnerable farmers in the States and Nigeria in general are to COVID-19 pandemic. 


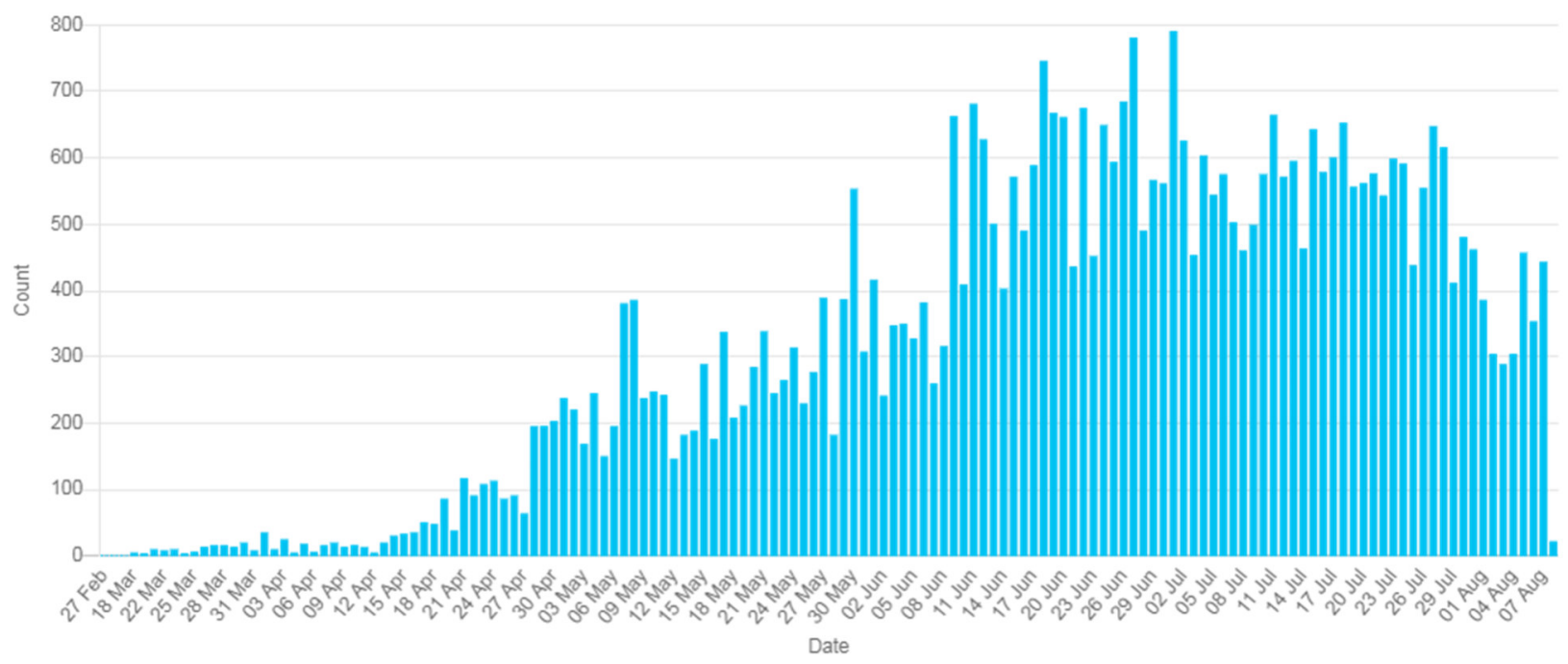

Figure 1: Epi-curve of Confirmed COVID-19 Cases in Nigeria as at $7^{\text {th }}$ August 2020 [5]

\section{Confirmed COVID-19 cases in Africa over time}

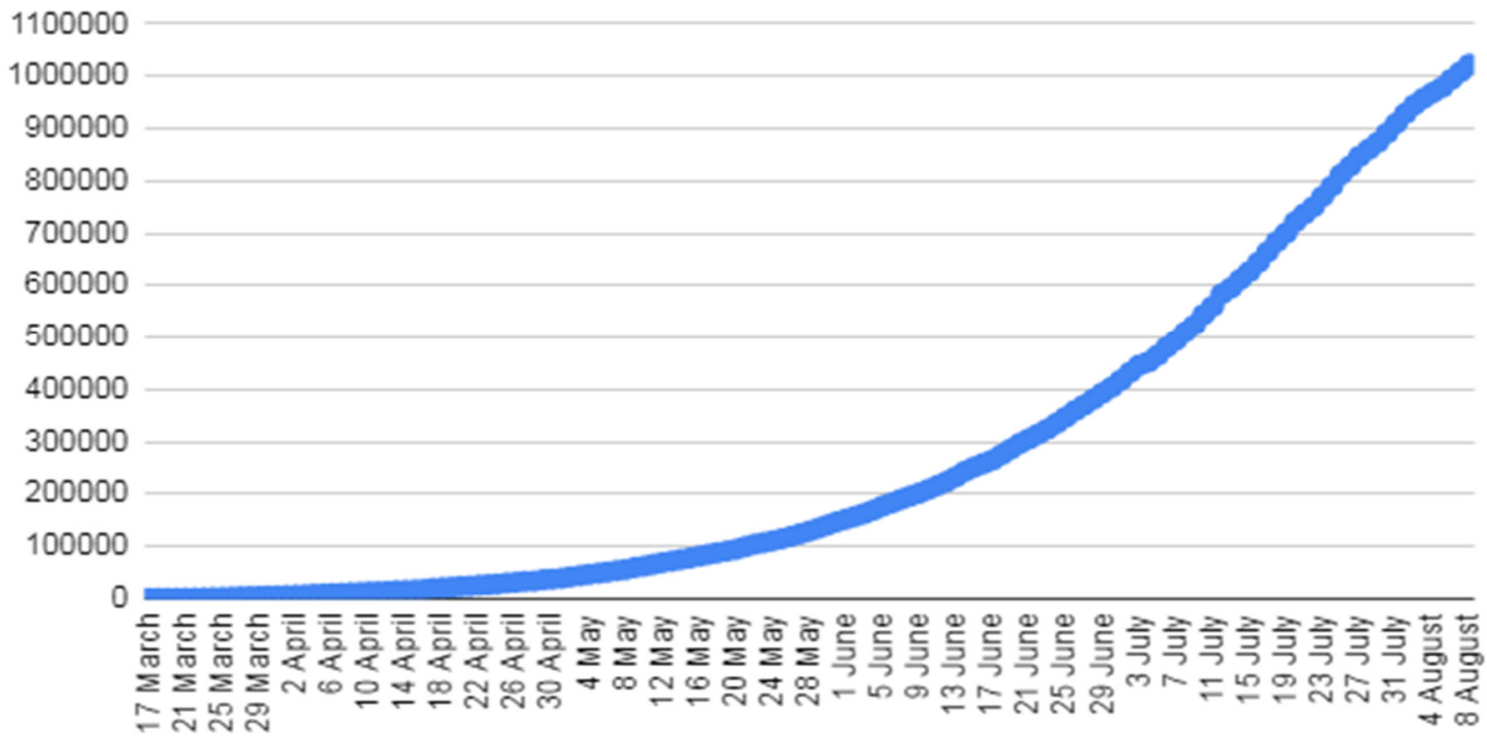

Figure 1: Confirmed COVID-19 Cases in Africa Overtime as at $8^{\text {th }}$ August 2020 [4]

\section{Specific Objectives of the Study}

The study was logically and specifically guided by;

i. $\quad$ describing the socio-economic characteristics of the rice farmers;

ii. developing and describing the conceptual framework linking the effect of COVID-19 pandemic in rice farming;

iii. determining the awareness of COVID-19 pandemic among rice farmers;

iv. $\quad$ identifying farmers sources of information on COVID-19 pandemic;

v. identifying the COVID-19 pandemic precautionary measures farmers are practcing;

vi. ascertaining the perceived effect of COVID-19 pandemic on rice yield and

vii. identifying the barriers in mitigating COVID-19 pandemic in rice farming.

\section{METHODOLOGY}

The study was carried-out in South-East agricultural zone of Nigeria. The zone is made up of five states, namely, Abia, Anambra, Ebonyi, Enugu and Imo. It has an estimated land mass of $32,610 \mathrm{~km}^{2}$ and a population of $22,583,076[11,12]$. The area lies between longitude $2^{\circ} 61^{1}$ and $6^{0} .32^{1}$ East and latitudes $6^{\circ} 74^{1}$ and $8^{\circ} 15^{1}$ North of Equator with the mean annual temperature ranges from $21.6^{\circ} \mathrm{C}$ to $32.4^{\circ} \mathrm{C}$ while the annual rainfall ranges from 720 
$\mathrm{mm}$ to $1440 \mathrm{~mm}$ in the rainforest region [13]. South-East Nigeria has two distinct ecological zones - the tropical rainforest to the South and derived guinea savanna to the North [15]. South-East Nigeria has fertile and welldrained soil and a good proportion of the population are essentially farmers. The sample for the study was drawn from rice farmers in the study area.

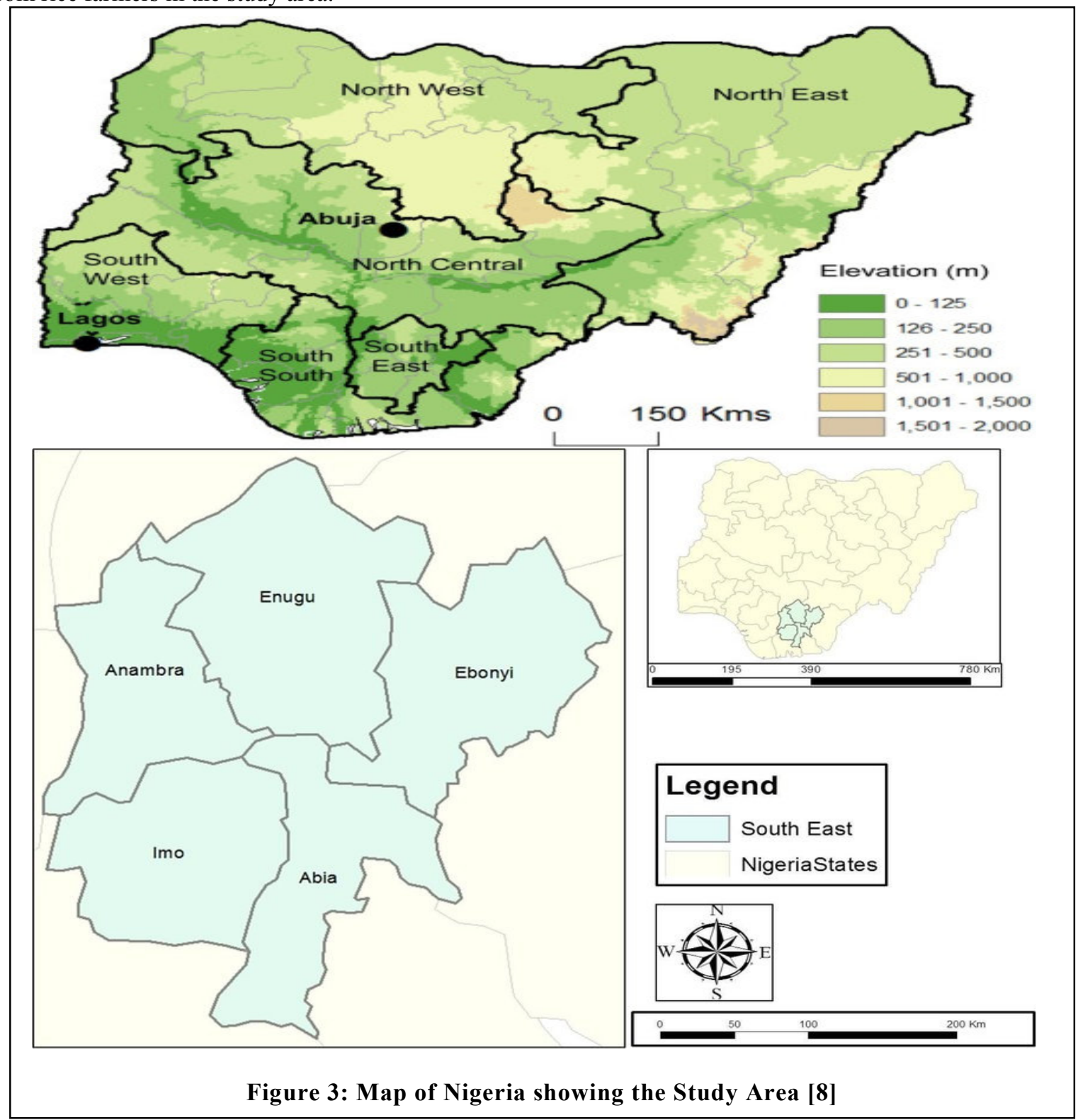

i. Sampling Technique

A multi-stage random sampling procedure was adopted in the selection of respondents for the study. Secondly, three Local Government Areas (LGAs) were purposively selected from each of selected States giving a total of nine (9) local government areas for the study. Firstly three (3) States was randomly selected from the five (5) geopolitical zone of South-East, Zone of Nigeria. Secondly, three Local Government Areas (LGAs) was purposively selected from each of selected States giving a total of nine (9) local government areas for the study. Thirdly, three (3) communities were purposively selected from each of the nine (9) selected LGAs based on the concentration of rice farmers to give a total of twenty-seven (27) communities.

Finally, stratified random sampling techniques was used to select 14 crop rice farmers from each of the 27 selected communities to give a total sample size of 504 respondents for the study. The list of farmers in the communities, which forms the sample frame, was obtained from the zonal extension agents of each of the State Agricultural Development Programme in the selected States.

\section{ii. Data Collection and Data Analysis}

Primary data was used for the study. Primary data was collected through the use of structured questionnaire and it was supplemented with interview schedule in places where the respondents could neither read nor write. The author developed and used a COVID-19 risk and effectiveness questionnaire to elicit data from the respondents. 
The questionnaire was contained both open and closed ended form of questions. Similarly, the questionnaire was properly subjected to content validity with the help of the research supervisors before administrating it to the respondents. The questionnaire was divided into five sections. Section one covered the socio-economic characteristics of the farmers. Section two dealt identifying the awareness to COVID-19 and sources of information on COVID-19 pandemic; Section three focused on determining COVID-19 pandemic precautionary measures use among farmers; section four measure the perceived effect of COVID-19 pandemic on rice yield and while section five identified the constraints in mitigating COVID-19 pandemic in rice farming. The survey was conducted at the onset of discovering of the index case of COVID-19 in Nigeria (27 February 2020) that is, from March to July 2020 with the help of two-hundred (200) enumerators i.e forty (40) for each State.

This study used descriptive statistical tools in analyzing the data. Descriptive statistics such as frequency distribution, percentages, mean, flow charts and 4-point likert scale type was used to analyze the data so as to realize objectives. The 4-point likert scale type was given as follows; $4=$ Very High effectiveness; $3=$ Highly effective; $2=$ Moderately effective and $1=$ Not effective.

$$
\begin{aligned}
& 4+3+2+1=10 / 4 \ldots \ldots \\
& =2.50 \text { cut-off point. }
\end{aligned}
$$

\section{Conceptual Framework for the Effect of COVID-19 in Rice Farming}

The conceptual framework that guided this study was developed by the authors based on literature review and field work is presented in figure 4, it provides a clear links between independent or explanatory variables and dependent variables as well as summarizes the mechanisms through which COVID-19 pandemic affects rice farmers livelihood, farm resources, labour, rice production, health status, access to market, food security. To examine the effects of COVID-19 on rice farming, the author developed a concept to link the important variables as shown in figure 4. Microeconomic explanation of individual and household poverty revolves around the understanding that an individual's labor (health and energy), human capital (education and skills), and physical and social assets (such as land and access to a social network) determine the individual's ability to generate income both today and in the future $[17,18,21]$.

From figure 3, Illness results in morbidity and sometimes mortality. These reduce labour availability through absenteeism or death of agricultural producers/worker. Through morbidity the quantity and quality of labour to the household is also affected because the sick may abstain completely or partially from work during the period of illness. Additionally, from Figure 4, labour availability is also indirectly affected when labour of productive members of the household is diverted from the farm to caring for the sick. When sick persons die, the knowledge that they acquired through learning and experience is no longer available for others to use and considerable rice agricultural knowledge is lost. However, it must be pointed out that although chronic illness (COVID-19) results in a net decrease in household labour (the ill and the caretaker), the death of a chronically ill person who had a full-time caretaker can result in increased household labour when the caretaker returns to the workforce. This is true as production, adaptation to climate change and mitigation GHGs emissions in rice field are costly [8,10,19].

Moving forward, from figure 3, the cost of healthcare for sick persons from COVID-19, and its protocols and of funerals drive many households into debt, and they resort to using their savings and remittances they receive or even sell household and farm assets to defray the costs. For instance, due to costs of treatment, cost of COVID-19 protocol and other expenses as well as lower incomes from loss of labour, COVID-19 affected households usually draw on assets from the farm. After the onset of COVID-19, savings and financial assets are usually the first to be depleted. Then, non-productive assets, such as furniture, cooking utensils and clothes follow. Ultimately, households may have to sell off productive assets such as equipment, draught animals, and land.

The outcomes of these effects include reduction of farm sizes, cultivation of less-intensive improved rice varieties, reduction in the variety of rice field planted, and the increase in climate change impact and greenhouse gases emission. The study of $[8,20]$ found that rice field is a significant anthropogenic source of methane $\left(\mathrm{CH}_{4}\right)$ and nitrous oxide $\left(\mathrm{N}_{2} \mathrm{O}\right)$, two important greenhouse gases (GHGs). These outcomes affect livelihoods in terms of reduction in rice farm outputs and income, a decline in income from wage labour, rice yield, market access, offfarm activities, and food insecurity. 


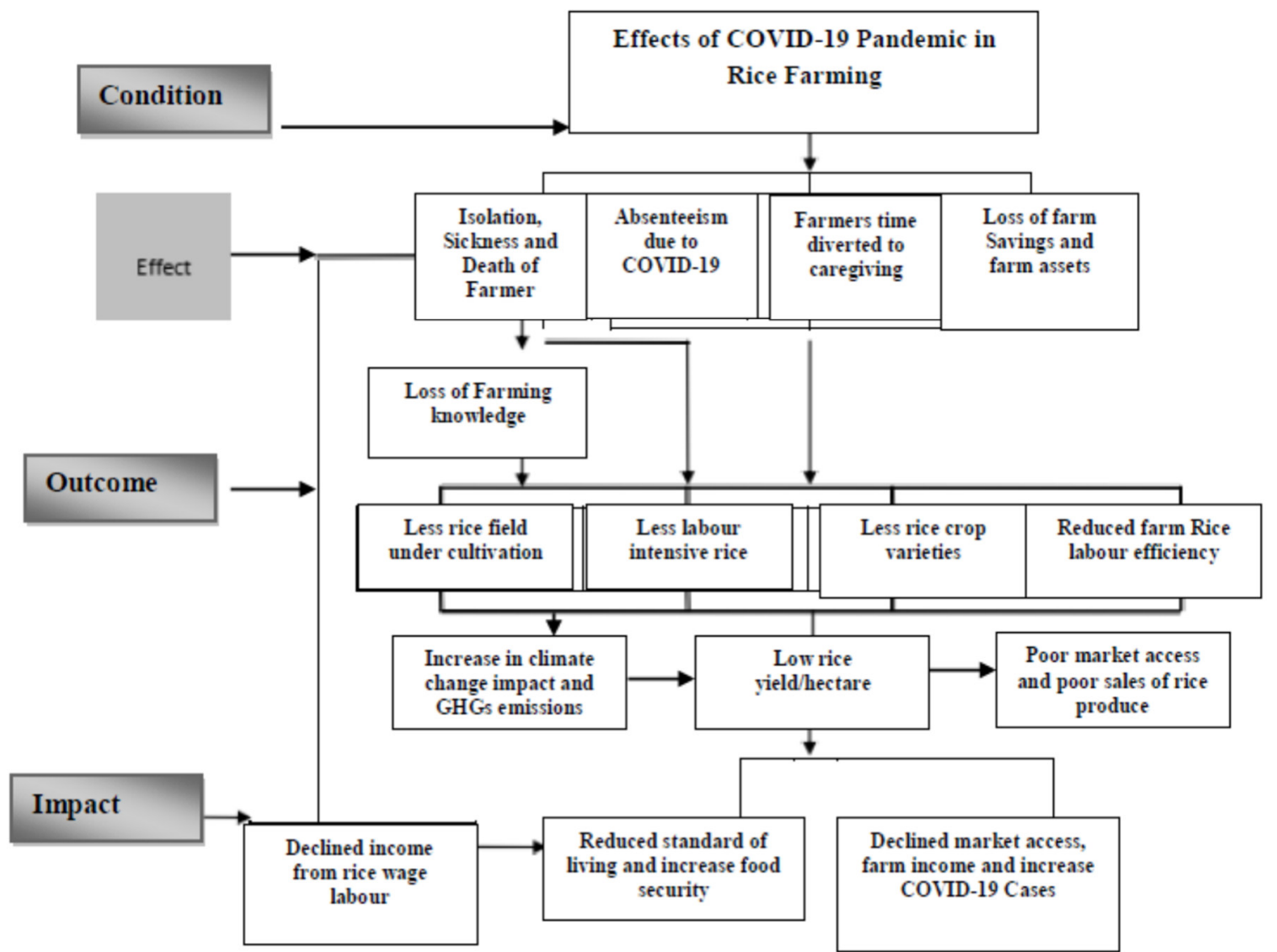

Figure 4: Conceptual Framework for the Effect of COVID-19 in Rice Farming (Researcher's own Construct, 2020)

\section{RESULTS AND DISCUSSION}

\section{Socio-economic Characteristics of Rice Farmers}

Table 1 revealed that majority (58.53\%) fell within the age range of 41-50 years. The mean age was 45.00 years. This shows that farmers in the area are vibrant, young and still within the active age. Rice farming is so strenuous. The implication is that younger farmers are more likely to practice more and modern farming method in reducing the effect of COVID-19 faster than the older ones. Young farmers are more likely to know about new strategies to avert COVID-19 effect with the willingness to bear risk. Table 1 also reveals that majority (61.30\%) of the farmers were males. The finding implies that both sex are involved in rice farming but male are more in number in the area. This is true as male farmers has been found to be more relatively efficient that women farmers [22].

TABLE 1: Socio-economic Characteristics of Rice Farmers

\begin{tabular}{|l|l|l|l|}
\hline Age (years) & Frequency & $\begin{array}{l}\text { Percentage } \\
(\mathbf{\%})\end{array}$ & Mean (X) \\
\hline $21-30$ & 8 & 1.58 & \\
\hline $31-40$ & 49 & 9.72 & \\
\hline $41-50$ & 295 & 58.53 & \\
\hline $51-60$ & 108 & 21.42 & \\
\hline $61-70$ & 32 & 6.34 & \\
\hline $71-80$ & 12 & 2.38 & \\
\hline Total & $\mathbf{5 0 4}$ & $\mathbf{1 0 0 . 0}$ & 45.00 years \\
\hline Sex & Frequency & $\begin{array}{l}\text { Percentage } \\
(\mathbf{\%})\end{array}$ & \\
\hline Male & 309 & 61.30 & \\
\hline Female & 195 & 38.69 & \\
\hline Total & $\mathbf{5 0 4}$ & $\mathbf{1 0 0 . 0}$ & \\
\hline
\end{tabular}




\begin{tabular}{|c|c|c|c|}
\hline Educational Level & Frequency & $\begin{array}{l}\text { Percentage } \\
(\%)\end{array}$ & \\
\hline No formal education & 16 & 3.17 & \\
\hline Primary & 161 & 31.94 & \\
\hline Secondary & 291 & 57.73 & \\
\hline Tertiary & 36 & 7.14 & \\
\hline Total & 504 & 100.0 & $\begin{array}{l}12 \text { years equivalent to secondary } \\
\text { education }\end{array}$ \\
\hline Marital Status & Frequency & $\begin{array}{l}\text { Percentage } \\
(\%)\end{array}$ & \\
\hline Married & 270 & 53.57 & \\
\hline Single & 157 & 31.15 & \\
\hline Widowed & 54 & 10.71 & \\
\hline Divorced & 23 & 4.56 & \\
\hline Total & 504 & 100.0 & \\
\hline Farming Experience (Years) & Frequency & $\begin{array}{l}\text { Percentage } \\
(\%)\end{array}$ & \\
\hline $01-10$ & 15 & 2.97 & \\
\hline $10-19$ & 34 & 6.74 & \\
\hline $20-30$ & 284 & 56.34 & \\
\hline $31-40$ & 101 & 20.03 & \\
\hline $41-50$ & 59 & 11.70 & \\
\hline $51-60$ & 11 & 2.18 & \\
\hline Total & 504 & 100.0 & 21 years \\
\hline $\begin{array}{l}\text { Household Size (Number of } \\
\text { Persons) }\end{array}$ & Frequency & $\begin{array}{l}\text { Percentage } \\
(\%)\end{array}$ & \\
\hline $1-2$ & 3 & 0.59 & \\
\hline $3-4$ & 14 & 2.78 & \\
\hline $5-6$ & 29 & 5.78 & \\
\hline $7-8$ & 124 & 24.60 & \\
\hline $9-10$ & 222 & 44.04 & \\
\hline $11-12$ & 101 & 20.03 & \\
\hline $13-14$ & 11 & 2.18 & 9 persons \\
\hline Total & 504 & 100.00 & \\
\hline Extension Contact & Frequency & $\begin{array}{l}\text { Percentage } \\
(\%)\end{array}$ & \\
\hline Not at all & 430 & 85.32 & \\
\hline Once in a fortnight & 47 & 9.32 & \\
\hline Once in a month & 23 & 4.56 & \\
\hline Once in a year & 4 & 0.79 & \\
\hline Total & 504 & 100.0 & \\
\hline Access to Credit & Frequency & $\begin{array}{l}\text { Percentage } \\
(\%)\end{array}$ & \\
\hline Access & 401 & 79.56 & \\
\hline No-access & 103 & 20.44 & \\
\hline Total & 504 & 100.0 & \\
\hline Total & 504 & 100.0 & \\
\hline
\end{tabular}




\begin{tabular}{|l|l|l|l|}
\hline Farm Size (Ha) & Frequency & $\begin{array}{l}\text { Percentage } \\
(\mathbf{\%})\end{array}$ & \\
\hline $0.1-1.0$ & 52 & 10.32 & \\
\hline $1.1-2.0$ & 89 & 17.66 & \\
\hline $2.1-3.0$ & 263 & 52.18 & \\
\hline $3.1-4.0$ & 100 & 19.84 & $\mathbf{3 . 1 0 h a}$ \\
\hline Total & $\mathbf{5 0 4}$ & $\mathbf{1 0 0 . 0}$ & \\
\hline Annual Farm Income (N) & Frequency & $\begin{array}{l}\text { Percentage } \\
\mathbf{( \% )}\end{array}$ & \\
\hline $100,000-200,000$ & 13 & 2.58 & \\
\hline $200,001-300,000$ & 36 & 7.14 & \\
\hline $300,001-400,000$ & 28 & 5.56 & \\
\hline $400,001-500,000$ & 23 & 4.56 & \\
\hline $600,001-700,000$ & 74 & 14.70 & \\
\hline $700,001-800,000$ & 96 & 19.05 & \\
\hline $800,001-900,000$ & 223 & 44.25 & \\
\hline $900,001-1,000,000$ & 11 & 2.18 & \\
\hline Total & $\mathbf{5 0 4}$ & $\mathbf{1 0 0 . 0}$ & \\
\hline
\end{tabular}

\section{Source: Field Survey Data, 2020}

Entries in Table 1 also show that greater proportion (57.73\%) had secondary school education. The mean educational level is 12 years which is equivalent to secondary school education. The finding implies that approximately $96.83 \%$ of the farmers had formal education which is expected to increase their level of understanding on the effect of COVID-19 in rice farms and various strategies to practice in thwarting these new threats.

Result in Table 1 shows that majority (53.57\%) were married. The finding implies that rice farming is an enterprise of married individual who are expected to be responsible according to societal standard [8]. Married farmers have likelihood of adapting to the effect of COVID-19 pandemic easily than their unmarried counterpart since they have access to labour. During this period of COVID-19 pandemic, non-availability of labour is interrupting some harvesting and distribution activities of rice.

There are disruptions in supply chains for purchase of inputs because of poor transportation system and partial ease of lockdown. Therefore, married farmers have increased chance of adapting easily to COVID-19 than their counterpart since they have access to households size. Result of farming experience is shown in Table 1 and it shows that about $56.34 \%$ of the farmers had a farming experience ranging from $20-30$ years. The mean year of experience in farming was 21.00 years. This shows that the farmers were quite experienced in rice farming and have started been practicing several COVID-19 pandemic strategies to increase their farm yield and income in the area. It is expected that farmers with more experience are more likely to accept innovations and new COVID-19 pandemic strategies to increase their farm yield and income than inexperienced farmer. The number of years of farming helps to cushion the effects of COVID-19 pandemic, since the incidence of diseases and infection is a recurring decimal globally such as the Spanish flu, 1918; AIDS pandemic and epidemic, 1981; H1N1 Swine Flu pandemic, 2009-2010; West African Ebola epidemic, 2014 and Zika Virus epidemic, 2015 amongst others.

Result in Table 1 also show that majority (85.32\%) of the farmers had no contact with extension agents. The COVID-19 procotol such as the restriction of movement have made it very difficult for extension agents to visit various farm families. Although, the use of video-conferences have been identified as a way to bridge the gap. Regrettably, rural farmers lack access, fund and technical-know-how to use it. The implication is that majority of the farmers may not have the opportunity of learning new COVID-19 farming strategies and consequently exposing their rice farming to incidence COVID-19 pandemic impact in the area. It becomes clear that there is need for the government to strengthen the Agricultural Development programme (ADP) of the various Southeast State with modern ICTs gadgets and skills for personnel to facilitate timely extension contacts with farmers in the area. Entries in Table 1 revealed that about $44.04 \%$ had a household size ranging from 9-10. The mean household size was found to be 9.00 persons. The result shows that farmers had large households.

The lockdown created both a shortage of farm labour The implication is that they could draw farm labour from their households during this period of COVID-19 to increase their farm yield and income. Table 1 revealed that majority (52.18\%) of the farmers had farm size of between $2.10-3.00$ hectares. The average farm size is $3.10 \mathrm{ha}$. 
The finding implies that the farmers in the area are mainly smallholder farmers operating on less than or equal to 3.50 hectares of farmland. This could be as a result of land tenure system or increasing population prevalent in the area. Additionally, the small farm size is not even contiguous plot but rather small plots scattered in different areas of the community. It is expected that farmers with large farm size will practice more and better COVID-19 strategies than those with lesser farmland in the area.

Finally, Table 1 indicates that majority $(54.14 \%)$ had an average annual farm income of between N800,001N900,000. The mean annual farm income was N880,200.00 (2,267.62USD) while monthly farm income was estimated to be $\mathrm{N} 73,350.00$ (188.97USD). The finding implies that the farmers have a relatively low farm income despite the larger household size which they recorded. The implication of the findings is that farmers may not have the much needed financial capacity to mitigate to the negative effect of COVID-19 pandemic in their rice farming. This is true as some mitigation strategies to COVID-19 pandemic strategies are costly. Hence, farmers may have several COVID-19 pandemic strategies they want to practice but limited fund may continue to hinder them.

\section{RICE FARMERS' AWARENESS OF COVID-19 PANDEMIC}

The result in Figure 5, shows farmers' awareness of COVID-19 Pandemic in the area. It shows that larger percentages (97.92\%) of the farmers are aware of COVID-19 Pandemic while approximately $2.08 \%$ are not aware of COVID-19 Pandemic in the area. The finding shows greater proportion of that farmers are aware of COVID19 Pandemic and may have been witnessing the negative effect. Additionally, farmers may have also developed sustainable COVID-19 pandemic strategies to thwart the negative effect of COVID-19 Pandemic to improve their farm yield, income and standard of living. The high awareness could be attributed to the massive publicity about the virus by various Nigeria news agencies, and agricultural extension agents. The extension agents have been called to help bridge gap in information for farmers.

The COVID-19 pandemic is not the first time extension agents have been called to action in an unfolding disaster. As an institution with trained technical staff who are trusted by communities, and with local reach and communication skills, extension agents has supported efforts and educated communities during crises such as HIV/AIDS, Ebola, avian influenza, natural disasters, and pest infestations. In the same way, even though, awareness does not really signify development and use/practice of modern COVID-19 pandemic strategies, however, it could serve as an essential determinate. Ultimately, quick action from the governments coupled with credible, regular information is critical in dealing with emergencies such as COVID-19. As a critical actor in providing such information to rural areas, extension agents can do several things globally to help mitigate the economic and health impacts of COVID-19.

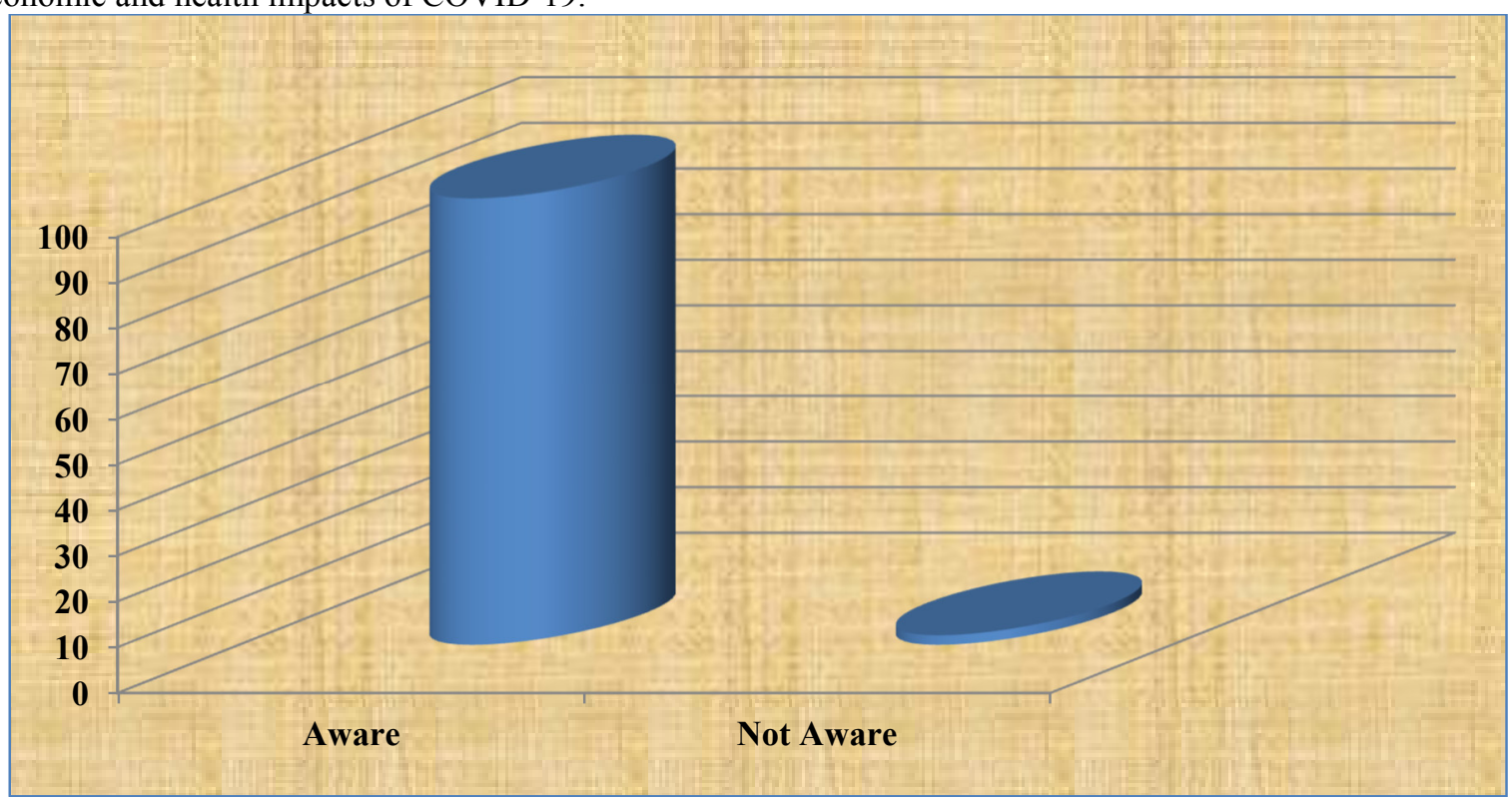

Figure 5: Rice Farmers' Awareness of COVID-19 Pandemic

\section{FARMERS' SOURCES' OF INFORMATION OF COVID-19 PANDEMIC}

The result in Figure 6, shows farmers sources' of information of COVID-19 pandemic in the area. It reveals that about $99.50 \%$ and $93.02 \%$ of the farmers source of information was radio and mobile phone (Bulk Text messages) respectively. The merging and use of technology particularly during this period of COVID-19 pandemic, that is, telephone (Bulk SMS) and radio has made it more accessible to many. Farmers are able to go everywhere with their radios, including to their farms. Every home had a radio while others had more than one radio. Radio is one 
of powerful communication tool and has proved to be the most effective media in promoting agriculture and development in rural areas, particularly as a tool for the delivery of quick information.

The result is strengthened by the finding of [23] who found that radio leads in overall media consumption followed by the mobile phone (Bulk Text messages) with the wake of many vernacular radios which are able to effectively communicate to the targeted groups. The result also shows that simple majority ( $48.73 \%$ and $12.62 \%)$ of the farmers identified extension agents and television as one of the sources of information on COVID-19 pandemic. Therefore, it should be a call for serious concern. For poor extension service delivery, it could be attributed to poor extension contact observed earlier from the socio-economic variable of the farmers in the study. Agricultural extension agents can offer great support to farmers during uncertainty and sudden changes that come with the pandemic, and strategies to bounce back from shocks and enhance resilience.Television is one of the possible mechanisms to activate already existing mental skills in the farmers. Television combines multiple symbol systems, such as visual images, sounds, music, spoken and written language, and presents them simultaneously. Regrettably, poor power supply and high cost of television-set have made it difficult for farmers to assess COVID19 information thorough it.

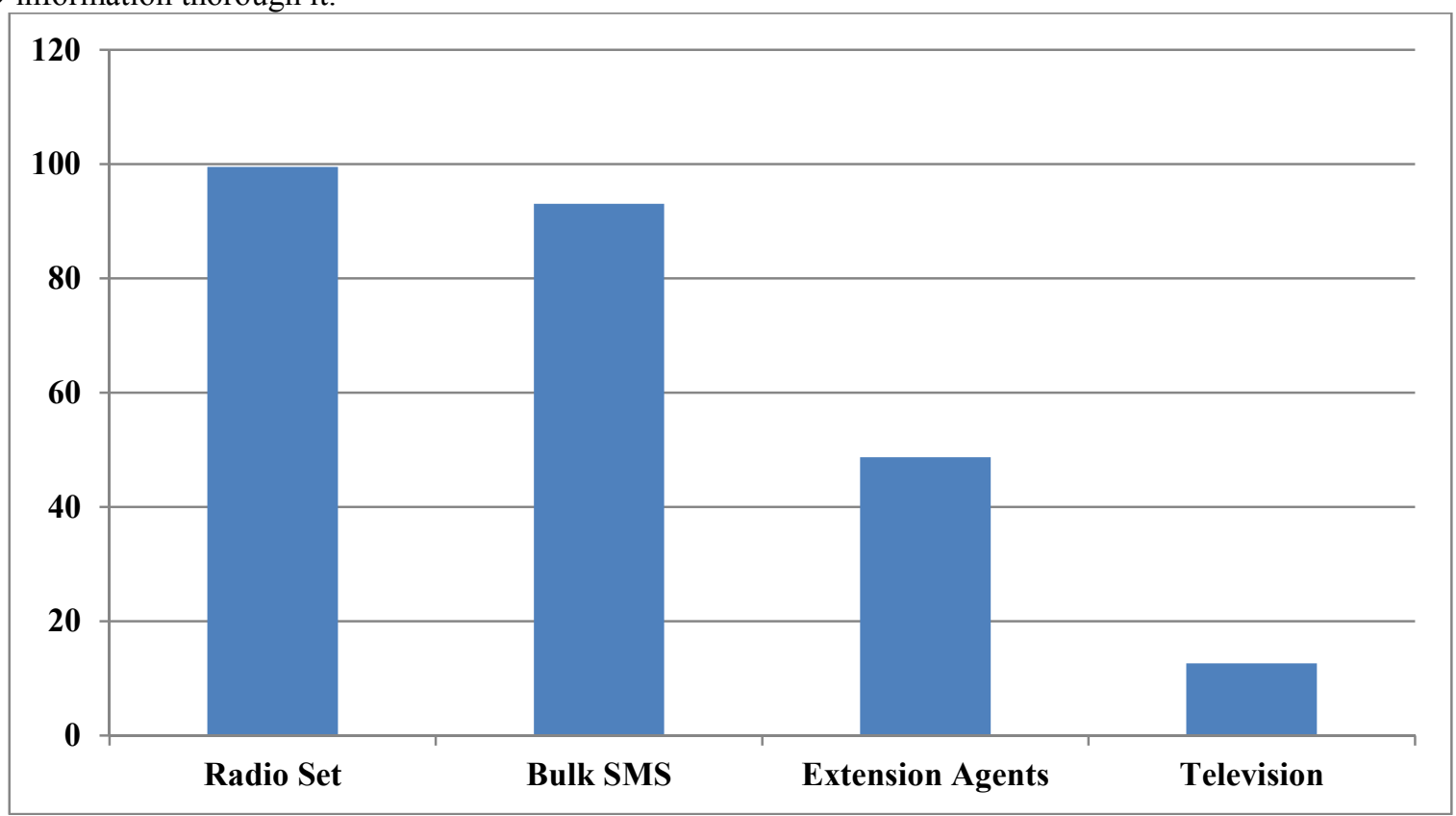

Figure 6: Farmers' Sources' of Information of COVID-19 Pandemic

\section{FARMERS' HEALTH PRECAUTIONARY MEASURES IN FACE OF COVID-19 PANDEMIC} The result in Figure 7, shows farmers health precautionary measures in face of COVID-19 pandemic in the area. It reveals that about $99.99 \%, 99.78 \%, 98.00 \%$ and $95.72 \%$ of the farmers have started hand washing, wearing a face mask, practising no-shake and physical/social distancing respectively. The [1] reported that masks can help prevent the spread of the virus from the person wearing the mask to others. The report when further to state that masks alone do not protect against COVID-19, and should be combined with physical distancing and hand hygiene. It is important to note that farmers who say to have started using a face mask were because of the local force abuse of the process. Most farmers said they wear a mask to avoid Nigerian police, taskforce and other health agency harassment and not for the fear of contracting the virus. In addition, [3] washing of hands is one of the most important steps one can take to avoid getting sick and spreading germs to others. Many diseases and conditions are spread by not washing hands with soap and clean, running water. The [1] recommends cleaning hands in a specific way to avoid getting sick and spreading germs to others. The guidance for effective hand-washing and use of hand sanitizer was developed based on data from a number of studies [24]. About 76.83\% have started heavy consumption of fruits and vegetables while a smaller proportion $(33.72 \%)$ said that Blood of Jesus Christ protects them and they do not and will not practice any measure. The report of [24] has advised people to Use fresh ingredients and those that have a shorter shelf life first.

The study of [1,24] further states that if fresh products, especially fruits, vegetables and reduced-fat dairy products continue to be available, prioritize these over non-perishables. Frozen fruits and vegetables can also conveniently be used over longer periods of time and often have a similar nutrient profile to fresh foods. The author founds out that most farmers do not trust the government and think that COVID-19 is a hoax and means the Nigerian Government and other world leaders want to use and embezzle public fund. This situation, therefore, calls for urgent concern for the global and Nigerian Government to show great sincere and accountable leadership 
to its citizens at all time.

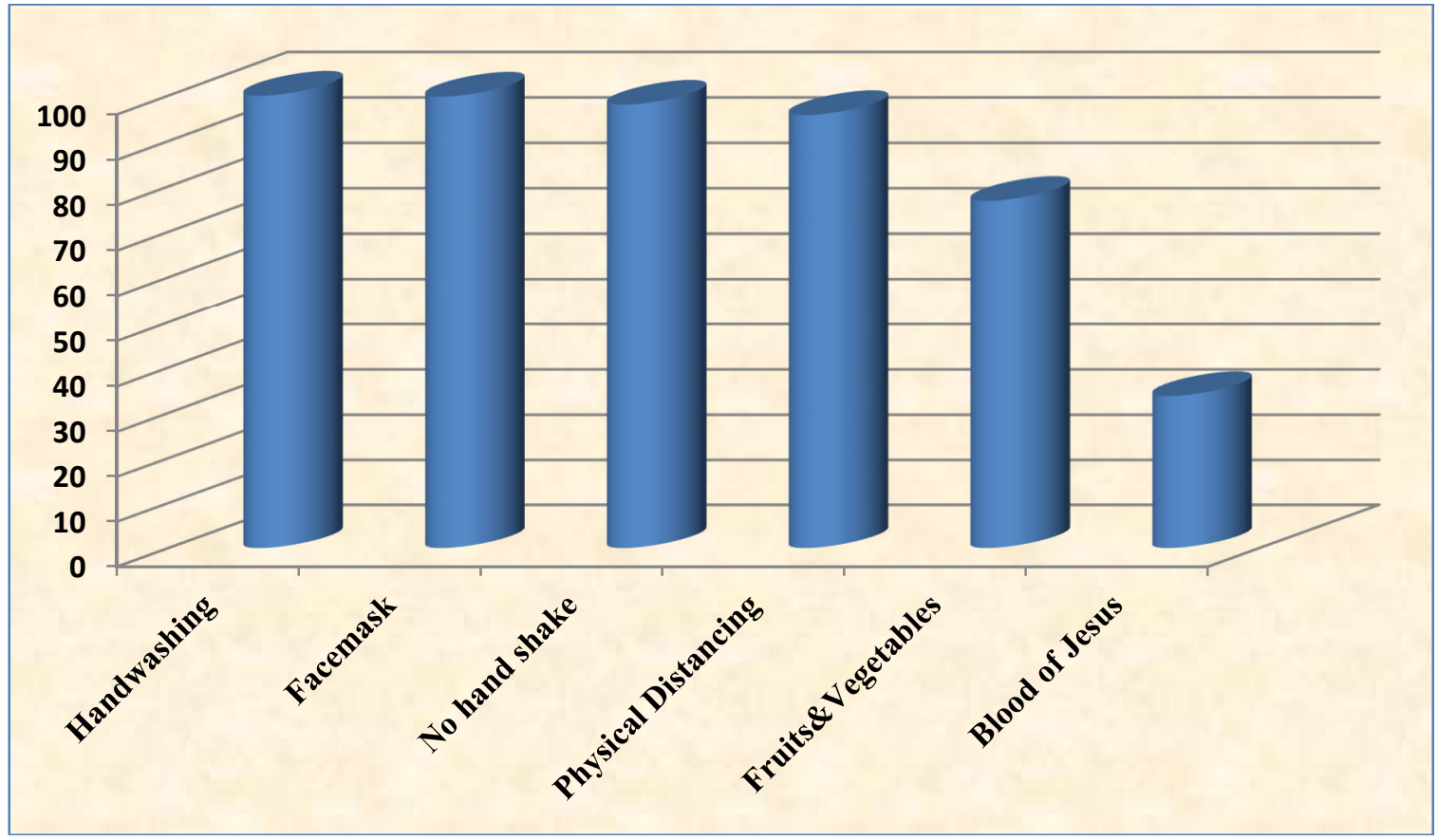

Figure 7: Farmers' Health Measures in COVID-19 Pandemic

\section{FARMERS' PERCEIVED EFFECT OF COVID-19 PANDEMIC IN RICE FARMING}

The result of the farmers' distribution based on perceived effect of COVID-19 pandemic in rice farming is compiled in Table 2. The various attributes of were rated in a 4- point likert scale type of questions of Strongly Agreed (4); Agreed (3); Disagreed (2) and Strongly Disagreed (1). Using the method of mean score analysis, a discriminatory mean of 2.50 was produced which divided the distribution into four scale was produced. The mean value of each attribute equal to or above $(\overline{\mathrm{X}}=\geq 2.50)$ was regarded as being an accepted decision while attributes with mean value less than $(\overline{\mathrm{X}}=\leq 2.50)$ was regarded as a rejected decision. The values of standard deviation (SD) denote the degree of variation in the responses of the farmers. Standard deviation with values equal or above one indicates high variances in farmers a response regarding level of knowledge of organic farming practices. The standard deviation value which ranged from $0.10-0.40$ indicated that farmers were in agreement in their perceived effective of organic farming practices on poverty alleviation in the area. Additionally, all the items were rated high and had an acceptable overall discriminatory score $(\bar{x}=\geq 2.50)$. This result strongly confirmed that COVID-19 pandemic is seriously affecting rice farmers in the area. A very salient finding was that COVID-19 pandemic is disrupting activities in rice value-chains $(\overline{\mathrm{x}}=\geq 3.11)$.

The result also showed that the COVID-19 pandemic has led to the partial restriction of all agricultural institutions in the country since March 2020 and disrupted rice activities, like harvesting of 2019/2020 season's rice produce that was ongoing and land preparations and planting for 2020/2021 season. Result show that the nonavailability of labour is interrupting planting, harvesting and distribution activities of rice $(\bar{x}=\geq 3.32)$. There are disruptions in supply chains for purchase of inputs because of poor transportation system and partial lockdown $(\bar{x}=\geq 3.12)$. Rice farmers are also paying more on inputs $(\bar{x}=\geq 3.43)$. Result also shows that extension visits to farmers have been seriously and market access limited ( $\bar{x}=\geq 3.44)$ due to the COVID-19 pandemic. With its farreaching geographical spread, the findings confirmed the study of [24] which reported that the pandemic is projected to have devastating effects on the global economy, as attested by the projection of the International Monetary Fund (IMF) in April 2020 that the world economy would contract sharply by 3.00\%, and that the economy of sub-Saharan Africa would contract by $1.60 \%$ in 2020 .

Furthermore, Economic Commission for Africa (ECA) has projected that, in a worst-case scenario, economic activity for Africa as a whole would contract by $2.60 \%$, with negative impacts on the employment rate, agriculture and that estimated that four out of five businesses in Africa would be significantly affected by the COVID-19 pandemic [25]. Going forward, the African Development Bank (AfDB) predicted an economic contraction for the continent of 3.40\% [26]. The study of [29] asserted that in order to mitigate the shock of the pandemic and its related effects on smallholder farmers building capacities and providing financial and marketing support for farmers would be essential. Similarly, food security is fragile under normal circumstances for smallholder farm families and other vulnerable populations across Southeast, Nigeria. As noted in an impact analysis from International Food Policy Research Institute (IFPRI), projections for increased poverty levels and food insecurity 
are dire as a result of the pandemic [30].

With this present threat, African countries and particularly Nigeria are likely to experience a reversal in the development gains already achieved and will be unlikely to achieve the United Nations 2030 Sustainable Development Goals and the aspirations of African Agenda 2063. The study therefore identified the need for governments at all levels in the country to design a sustainable policy in such a way that farmers should have access to affordable farm credit as well as subsidized agricultural inputs in order to increase their ability and flexibility to change in production strategies in response to COVID-19 pandemic.

Table 2: Farmers' Perceived Effect of COVID-19 Pandemic in Rice Farming

\begin{tabular}{|c|c|c|c|c|c|c|c|c|}
\hline S/No & Items & $\begin{array}{l}\text { Strongly } \\
\text { Agreed }\end{array}$ & Agreed & Disagreed & $\begin{array}{l}\text { Strongly } \\
\text { Disagreed }\end{array}$ & $\begin{array}{l}\text { Mean } \\
(\overline{\mathbf{x}}) \\
(\geq 2.50)\end{array}$ & SD & Decision \\
\hline 1 & $\begin{array}{l}\text { COVID-19 } \\
\text { pandemic has } \\
\text { brought a new } \\
\text { threat to our rice } \\
\text { farming }\end{array}$ & $\begin{array}{l}298 \\
(59.12)\end{array}$ & $\begin{array}{l}139 \\
(27.58)\end{array}$ & $\begin{array}{l}65 \\
(12.90)\end{array}$ & $\begin{array}{l}2 \\
(0.40)\end{array}$ & 3.22 & 0.85 & Accepted \\
\hline 2 & $\begin{array}{l}\text { COVID-19 } \\
\text { pandemic is } \\
\text { disrupting planting } \\
\text { of } 2020 / 2021 \\
\text { season seedling, } \\
\text { harvesting } \\
2019 / 2020 \text { of } \\
\text { produce } \\
\text { distribution and } \\
\text { activities in rice } \\
\text { farming. }\end{array}$ & $\begin{array}{l}261 \\
(51.79)\end{array}$ & $\begin{array}{l}155 \\
(30.75)\end{array}$ & $\begin{array}{l}83 \\
(16.47)\end{array}$ & $\begin{array}{l}5 \\
(0.10)\end{array}$ & 3.11 & 0.72 & Accepted \\
\hline 3 & $\begin{array}{l}\text { COVID-19 } \\
\text { pandemic has led } \\
\text { to a shortage of } \\
\text { farm labour }\end{array}$ & $\begin{array}{l}327 \\
(64.88)\end{array}$ & $\begin{array}{l}132 \\
(26.19)\end{array}$ & $\begin{array}{l}42 \\
(8.33)\end{array}$ & $\begin{array}{l}3 \\
(0.60)\end{array}$ & 3.32 & 0.56 & Accepted \\
\hline 4 & $\begin{array}{l}\text { COVID-19 } \\
\text { pandemic has } \\
\text { decreased supply } \\
\text { chains for purchase } \\
\text { of inputs because } \\
\text { of the poor } \\
\text { transportation } \\
\text { system and partial } \\
\text { lockdown }\end{array}$ & $\begin{array}{l}281 \\
(55.75)\end{array}$ & $\begin{array}{l}128 \\
(25.40)\end{array}$ & $\begin{array}{l}84 \\
(16.67)\end{array}$ & $\begin{array}{l}11 \\
(2.18)\end{array}$ & 3.12 & 0.52 & Accepted \\
\hline 5 & $\begin{array}{l}\text { COVID-19 } \\
\text { pandemic has led } \\
\text { to a decrease in the } \\
\text { provision of basics } \\
\text { food for our } \\
\text { children }\end{array}$ & $\begin{array}{l}301 \\
(59.72)\end{array}$ & $\begin{array}{l}103 \\
(20.45)\end{array}$ & $\begin{array}{l}98 \\
(19.44)\end{array}$ & $\begin{array}{l}2 \\
(0.40)\end{array}$ & 3.17 & 0.81 & Accepted \\
\hline 6 & $\begin{array}{l}\text { COVID-19 } \\
\text { pandemic has led } \\
\text { to an increase in } \\
\text { the cost of input } \\
\text { and machinery }\end{array}$ & $\begin{array}{l}375 \\
(74.40)\end{array}$ & $\begin{array}{l}97 \\
(19.25)\end{array}$ & $\begin{array}{l}31 \\
(6.15)\end{array}$ & $\begin{array}{l}1 \\
(0.20)\end{array}$ & 3.43 & 0.87 & Accepted \\
\hline 7 & $\begin{array}{l}\text { COVID-19 } \\
\text { pandemic has } \\
\text { decreased my rice } \\
\text { production/yield } \\
\text { and aggregate farm } \\
\text { income }\end{array}$ & $\begin{array}{l}293 \\
(58.13)\end{array}$ & $\begin{array}{l}144 \\
(28.57)\end{array}$ & $\begin{array}{l}58 \\
(11.51)\end{array}$ & $\begin{array}{l}9 \\
(1.79)\end{array}$ & 3.20 & 0.83 & Accepted \\
\hline
\end{tabular}




\begin{tabular}{|c|c|c|c|c|c|c|c|c|}
\hline S/No & Items & $\begin{array}{l}\text { Strongly } \\
\text { Agreed }\end{array}$ & Agreed & Disagreed & $\begin{array}{l}\text { Strongly } \\
\text { Disagreed }\end{array}$ & $\begin{array}{l}\text { Mean } \\
(\overline{\mathbf{x}}) \\
(\geq 2.50)\end{array}$ & SD & Decision \\
\hline 8 & $\begin{array}{l}\text { COVID-19 } \\
\text { pandemic has } \\
\text { made us unable to } \\
\text { provide the } \\
\text { recommended } \\
\text { health } \\
\text { precautionary } \\
\text { measures for our } \\
\text { family }\end{array}$ & $\begin{array}{l}382 \\
(75.79)\end{array}$ & $\begin{array}{l}112 \\
(22.22)\end{array}$ & $\begin{array}{l}7 \\
(1.39)\end{array}$ & $\begin{array}{l}3 \\
(0.60)\end{array}$ & 3.48 & 0.68 & Accepted \\
\hline 9 & $\begin{array}{l}\text { COVID-19 } \\
\text { pandemic have } \\
\text { negatively affected } \\
\text { our different rice } \\
\text { value chain }\end{array}$ & $\begin{array}{l}317 \\
(62.90)\end{array}$ & $\begin{array}{l}146 \\
(28.97)\end{array}$ & $\begin{array}{l}33 \\
(6.55)\end{array}$ & $\begin{array}{l}8 \\
(1.59)\end{array}$ & 3.30 & 0.75 & Accepted \\
\hline 10 & $\begin{array}{l}\text { COVID-19 } \\
\text { pandemic have } \\
\text { greatly increased } \\
\text { our farm } \\
\text { production, } \\
\text { harvesting and } \\
\text { distribution cost }\end{array}$ & $\begin{array}{l}303 \\
(60.12)\end{array}$ & $\begin{array}{l}101 \\
(20.04)\end{array}$ & $\begin{array}{l}88 \\
(17.46)\end{array}$ & $\begin{array}{l}12 \\
(2.38)\end{array}$ & 3.15 & 0.78 & Accepted \\
\hline 11 & $\begin{array}{l}\text { COVID-19 } \\
\text { pandemic have } \\
\text { negatively drew us } \\
\text { back in adapting } \\
\text { and mitigating to } \\
\text { climate change }\end{array}$ & $\begin{array}{l}297 \\
(58.93)\end{array}$ & $\begin{array}{l}120 \\
(23.81)\end{array}$ & $\begin{array}{l}61 \\
(12.10)\end{array}$ & $\begin{array}{l}26 \\
(5.16)\end{array}$ & 3.14 & 0.80 & Accepted \\
\hline 12 & $\begin{array}{l}\text { COVID-19 } \\
\text { pandemic have } \\
\text { negatively drew us } \\
\text { back in mitigating } \\
\text { to greenhouse } \\
\text { gases emission in } \\
\text { our rice field }\end{array}$ & $\begin{array}{l}308 \\
(61.11)\end{array}$ & $\begin{array}{l}105 \\
(20.83)\end{array}$ & $\begin{array}{l}87 \\
(17.26)\end{array}$ & $\begin{array}{l}4 \\
(0.79)\end{array}$ & 3.20 & 0.79 & Accepted \\
\hline 13 & $\begin{array}{l}\text { COVID-19 } \\
\text { pandemic have } \\
\text { negatively affected } \\
\text { our access to } \\
\text { market and } \\
\text { Agricultural } \\
\text { extension services }\end{array}$ & $\begin{array}{l}134 \\
(53.17)\end{array}$ & $\begin{array}{l}101 \\
(40.08)\end{array}$ & $\begin{array}{l}12 \\
(4.76)\end{array}$ & $\begin{array}{l}5 \\
(1.98)\end{array}$ & 3.44 & 0.81 & Accepted \\
\hline
\end{tabular}

SD; Standard Deviation; Discriminatory index: Cut off point $\bar{x} \geq 2.50$ Accepted; *Figures in parenthesis are percentage; Field Survey Data, 2020

\section{FARMERS' BARRIERS IN MITIGATING THE EFFECT OF COVID-19 PANDEMIC IN RICE FARMING}

The finding in Figure 8 shows farmers' barriers in mitigating the effect of COVID-19 pandemic in rice farming in the area. The finding reveals that about $99.82 \%$ of the farmers identified inadequate information. This could be attributed to the dearth in research on COVID-19 pandemic mitigation strategies for rice farmers as well as lack of information on clarity on the actionable guidance and precautionary measures by World Health Organization (WHO), Centre for Disease Control and Prevention (CDC), Nigeria Centre for Disease Control (NCDC) and local health authority. This constraint left the farmers unable to get the much-needed information on COVID-19 pandemic and sustainable rice farming. In the present information age, inadequate information could pose serious challenges to the farmers' coping strategies as they may not be aware of recent developments regarding COVID19 pandemic, mitigation strategies and the necessary re-adjustments needed. Meanwhile, crop farmers have been badly hit due to misinformation, particularly on social media, that crops and animals are the carriers of COVID- 
19. Also, poor/inadequate information on COVID-19 pandemic and sustainable strategies for rice farming may rise the food insecurity situation and lead to unsustainable rice production overtime.

Approximately $97.85 \%$ complained of the inadequate fund. The inadequate fund left most of the rice farmers unable to get necessary productive resources in mitigating the effect of COVID-19 pandemic in the area. This could be attributed to the sudden rise of rice productive resources due to lockdown and food shortage. Inadequate fund hinders farmers from getting the necessary resources and technologies which assist to mitigate efficiently to the effect of COVID-19 pandemic. The COVID-19 pandemic mitigation options are costly because of restrictions and input factory closure hence, farmers need adequate fund to adapt. Going forward, poor extension contact, high cost of labour, poor access to farm credit and no-COVID-19 pandemic palliative by the government were complained by $95.20 \%, 93.98 \%, 89.90 \%$ and $85.70 \%$ respectively of the rice farmers. The high cost of farm inputs could also be attributed to inadequate fund. With the limited fund, the acquisition of necessary production equipment will be difficult. They may not only be costly but may also appear scarce for poor farmers particularly ducting the period of the pandemic. Besides, the farmers may not also have the necessary facilities for information like radio and television to obtain COVID-19 report.

Poor access of credit could be linked to lack of information or awareness of the presence of loan facilities, high collateral and location of banks in urban which is far from the rural areas where farmers live. In the same way, the COVID-19 pandemic related transport restrictions make it particularly difficult for suppliers to get inputs like seeds, fertilizers, crop protection products and equipment to rice farmers in time for planting season, disrupting production of rice. Restrictions are also triggering additional higher labour cost, post-harvest losses, as unsold and rotting food accumulates on farms. Similarly, planting and harvesting season is imminent for rice farming and a shortage of labour and poor access to farm credit is leading to production losses and shortages in the market. In Nigeria, this comes on top of as one of the existing difficulties in sourcing rice production labour and finance. Most Nigerian were left unhappy with government selective provision of palliative. Some reports claimed that South-East Nigeria was the study was conducted never receive any form of palliative from the government. This situation left most of the farmers unable to mitigate the effect of COVID-19 pandemic in their rice farms.

About $78.28 \%$ identified lack of trust. Trust is the foundation upon which the legitimacy of public institutions is built and is crucial for maintaining social cohesion [32]. Most farmers do not trust the government and this leads to the farmers believing that the COVID-19 is real. Some believed, that the government wants to use the media to embezzle public fund. Similarly, many farmers gloat that COVID-19 is mainly targeting the politicians, despite warnings that the life-threatening respiratory illness could hit the poor farmers as well. Some farmers also hoped that the "selectiveness" of the virus might be God's way of bringing about changes leadership of Nigerian government. During this current COVID-19 pandemic, including containment, mitigation and recovery, trust in public institutions is vital for governments' ability to respond rapidly and to secure citizen support. Government's ability to harness public trust as a force out of the crisis will be crucial for planning and implementing an inclusive recovery from the COVID-19 emergency. It is important for the government to show great transparent and accountable leadership for the people to trust. Curbing this barrier will be vital in promoting not just local COVID19 mitigation strategies in increasing rice yield, farmers' livelihood, farmers' income and standard of living but global strategies in area and perhaps beyond. 


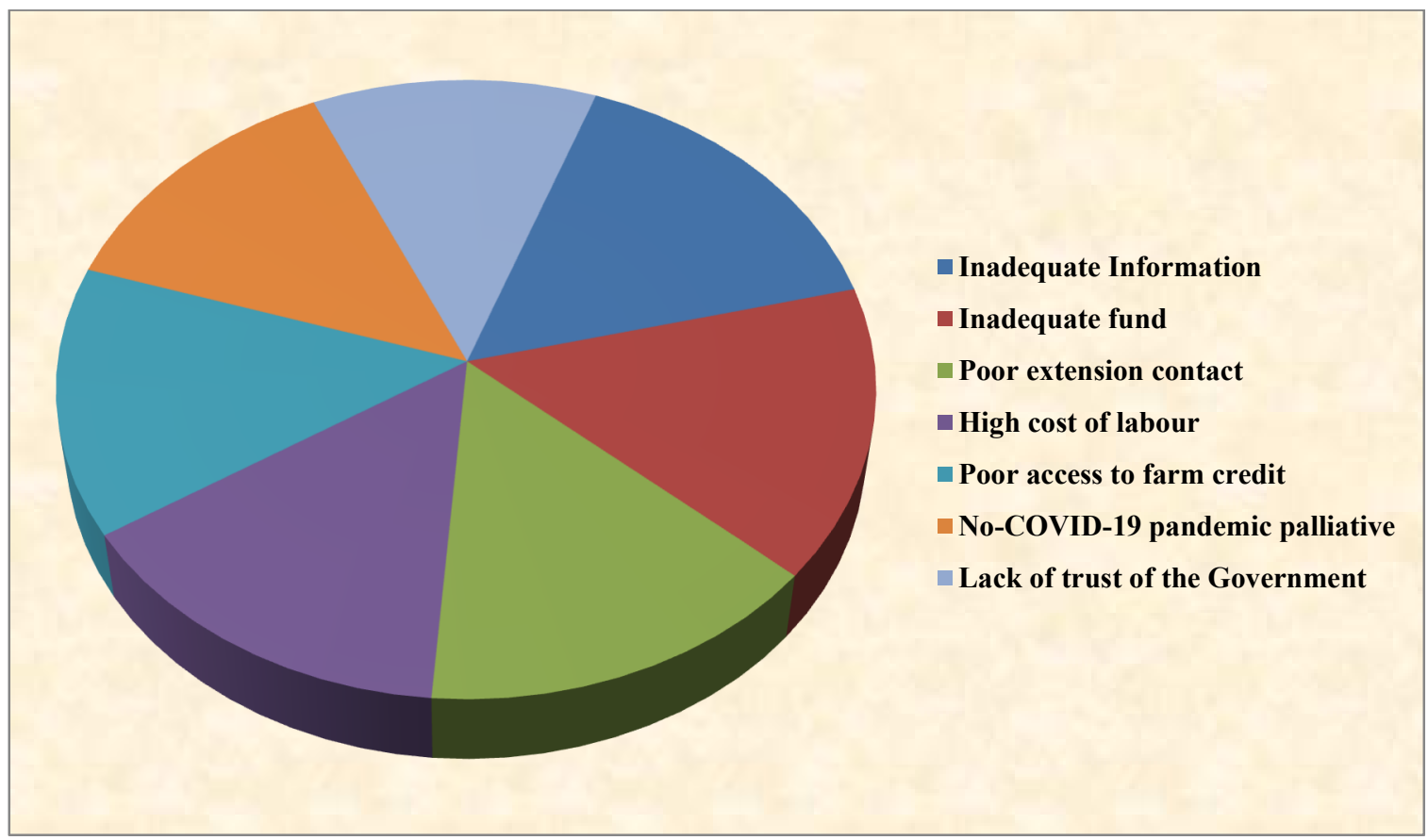

Figure 8: Farmers' Barriers in Mitigating the Effect of COVID-19 Pandemic in Rice Farming

\section{CONCLUSION}

The COVID-19 pandemic is having a great effect on the entire rice value chain, confirming in the most terrible way that we are all part of a rice value-chain system that is interconnected and fragile and that solutions must be developed together. Rice farming has been recognized almost worldwide as an essential activity and farmers were asked to keep on working, even harder, to cope up with this new challenge. Nevertheless, each component of the rice value-chain system has an impact on farming activities, so each bottleneck occurring somewhere on the rice value-chain system, is having an impact on farmers livelihood, farm yield and farm income. Countries lock-down and borders' closures are strongly impacting rice farmers' access to input like seeds, fertilizers and agrochemicals. In Nigeria, while rice farmers are still battling the negative impact of climate change and greenhouse gases (GHGs) emissions, the COVID-19 pandemic has brought a new risk that not only threatens farmers livelihoods but also the most important global food security crop "Rice". Every farming season in Nigeria, rice farmers face risks such as low rainfall, price volatility, methane emissions, rising debts and poor government policies. But the present risks from the COVID-19 pandemic are putting new challenges in front of rice value-chain that is already under serious threat.

Additionally, the growing demand for rice across SSA and particularly in Nigeria exceeds supply, resulting in a rice deficit. To overcome this challenge, rice yield should be increased particularly now there is new threat for farmers. As a matter of urgency, farmers must respond to this new threat (COVID-19) by choosing measures that increase their yield. Incidentally, empirical studies that documented the effect of COVID-19 pandemic on rice yield cannot be found as at the time of this study. These create emptiness in research and make it extremely difficult if not impossible for the government/interest group to know the method they can use in helping farmers mitigate the negative impact of COVID-19 pandemic in rice production. The study was logically guided by describing the socio-economic characteristics of the rice farmers; determining the awareness of COVID-19 pandemic among rice farmers; identifying farmers sources of information on COVID-19 pandemic; identifying the COVID-19 pandemic precautionary measures farmers are using; ascertaining the perceived effect of COVID19 pandemic on rice yield and constraints in mitigating COVID-19 pandemic in rice farming.

The survey was conducted at the onset of discovering of the index case of COVID-19 in Nigeria (27 February 2020) that is, from March to July 2020 with the help of two-hundred (200) enumerators i.e forty (40) for each State. A cross-sectional data was elicited from 504 rice farmers selected from Abia, Anambra, Ebonyi, Enugu and Imo State. Data collected were analyzed using descriptive statistical tools such as means, flow-chart, percentage and likert scale-type. Result show that the mean age was 45.00 years. Greater proportions $(61.30 \%)$ were male. Majority (53.57\%) were married with an average household size of 8 persons. Average educational level, farming experience and annual farm income were 12.00 years (equivalent to secondary education), 21.00years and N880,200.00 (2,267.62USD) respectively. Additionally, farmers may have also developed sustainable COVID-19 pandemic strategies to thwart the negative effect of COVID-19 Pandemic to improve their farm yield, income and standard of living. The high awareness could be attributed to the massive publicity about the virus by various 
Nigeria news agencies, and agricultural extension agents. The extension agents have been called to help bridge gap in information for farmers.

The COVID-19 pandemic is not the first time extension agents have been called to action in an unfolding disaster. As an institution with trained technical staff who are trusted by communities, and with local reach and communication skills, extension agents has supported efforts and educated communities during crises such as HIV/AIDS, Ebola, avian influenza, natural disasters, and pest infestations.

The conceptual framework that guided this study was developed by the authors based on literature review and field work is presented in figure 4 , it provides a clear links between independent or explanatory variables and dependent variables as well as summarizes the mechanisms through which COVID-19 pandemic affects rice farmers livelihood, farm resources, labour, rice production, health status, access to market, food security. To examine the effects of COVID-19 on rice farming, the author developed a concept to link the important variables as shown in figure 4. From figure 4, Illness results in morbidity and sometimes mortality. These reduce labour availability through absenteeism or death of agricultural producers/worker. Through morbidity the quantity and quality of labour to the household is also affected because the sick may abstain completely or partially from work during the period of illness.

Additionally, from Figure 4, labour availability is also indirectly affected when labour of productive members of the household is diverted from the farm to caring for the sick. When sick persons die, the knowledge that they acquired through learning and experience is no longer available for others to use and considerable rice agricultural knowledge is lost. The result in Figure 6, shows farmers sources' of information of COVID-19 pandemic in the area. It reveals that about $99.50 \%$ and $93.02 \%$ of the farmers source of information was radio and mobile phone (Bulk Text messages) respectively. The merging and use of technology particularly during this period of COVID19 pandemic, that is, telephone (Bulk SMS) and radio has made it more accessible to many. Farmers are able to go everywhere with their radios, including to their farms. Every home had a radio while others had more than one radio. Radio is one of powerful communication tool and has proved to be the most effective media in promoting agriculture and development in rural areas, particularly as a tool for the delivery of quick information. The result in Figure 7, shows farmers health precautionary measures in face of COVID-19 pandemic in the area. It reveals that about $99.99 \%, 99.78 \%, 98.00 \%$ and $95.72 \%$ of the farmers have started hand washing, wearing a face mask, practising no-shake and physical/social distancing respectively.

The [1] reported that masks can help prevent the spread of the virus from the person wearing the mask to others. The report when further to state that masks alone do not protect against COVID-19, and should be combined with physical distancing and hand hygiene. It is important to note that farmers who say to have started using a face mask were because of the local force abuse of the process. Most farmers said they wear a mask to avoid Nigerian police, taskforce and other health agency harassment and not for the fear of contracting the virus. This result strongly confirmed that COVID-19 pandemic is seriously affecting rice farmers in the area. A very salient finding was that COVID-19 pandemic is disrupting activities in rice value-chains $(\bar{x}=\geq 3.11)$. Result show that the nonavailability of labour is interrupting planting, harvesting and distribution activities of rice $(\overline{\mathrm{x}}=\geq 3.32)$. There are disruptions in supply chains for purchase of inputs because of poor transportation system and partial lockdown $(\bar{x}=\geq 3.12)$. Rice farmers are also paying more on inputs $(\bar{x}=\geq 3.43)$. Result also shows that extension visits to farmers have been seriously and market access limited ( $\bar{x}=\geq 3.44)$ due to the COVID-19 pandemic. With its farreaching geographical spread, the findings confirmed the study of [24] which reported that the pandemic is projected to have devastating effects on the global economy, as attested by the projection of the International Monetary Fund (IMF) in April 2020 that the world economy would contract sharply by 3.00\%, and that the economy of sub-Saharan Africa would contract by $1.60 \%$ in 2020 . The finding in Figure 8 shows farmers' barriers in mitigating the effect of COVID-19 pandemic in rice farming in the area. The finding reveals that about $99.82 \%$ of the farmers identified inadequate information. This could be attributed to the dearth in research on COVID-19 pandemic mitigation strategies for rice farmers as well as lack of information on clarity on the actionable guidance and precautionary measures by World Health Organization (WHO), Centre for Disease Control and Prevention (CDC), Nigeria Centre for Disease Control (NCDC) and local health authority. This constraint left the farmers unable to get the much-needed information on COVID-19 pandemic and sustainable rice farming. In the present information age, inadequate information could pose serious challenges to the farmers' coping strategies as they may not be aware of recent developments regarding COVID-19 pandemic, mitigation strategies and the necessary re-adjustments needed. Meanwhile, crop farmers have been badly hit due to misinformation, particularly on social media, that crops and animals are the carriers of COVID-19. Also, poor/inadequate information on COVID-19 pandemic and sustainable strategies for rice farming may rise the food insecurity situation and lead to unsustainable rice production overtime.

\section{RECOMMENDATIONS}

The following recommendations were made based on the major research observations and findings of the study.

i. The study identified inadequate and misinformation as one of the barriers farmers complained about, 
therefore, it is important that the government should intensify mass mobilization campaign against COVID-19 pandemic alongside the community leaders and extension agents to reduce, if not eliminate the spread of the deadly virus.

ii. The study authenticated the importance of linking education to the mitigation of COVID-19 pandemic in improving understanding, farm yield, farm income, the standard of living of the rice farmers. Therefore, it is necessary for the rice farmers on their owe should enrol for adult education to increase their ability and flexibility to change in production strategies in response to COVID-19 pandemic.

iii. Rice production-related constraints such as labour and other inputs mainly hindered farmers from mitigating the effect of COVID-19 effectively. Labour and input are in high demand and cost now due to restrictions. Therefore, the government must also design policy in such a way that farmers' should have access to affordable credit, farm labour as well as subsidized input to increase their rice production, the standard of living as well as encourage more farmers to go into rice farming.

iv. Effective agricultural policies and programmes should focus on how to intensify awareness on COVID19 pandemic in rice farm as well as its mitigation strategies. This should be done through strengthened agricultural extension service delivery.

v. Agricultural extension agents can offer support during uncertainty and sudden changes that come with the pandemic, and strategies to bounce back from shocks and enhance resilience. Therefore, capacity strengthening, the right tools and channels are necessary to provide tailored effective agricultural extension agents messages. The government should strengthen agricultural extension agents' service delivery.

vi. It is important to protect the community where these rice farmers are domiciled from exposure to the infection, all residents in the potential risk areas should be encouraged to stay at home, which is one of the most effective ways of blocking the transmission routes. Local community health workers and volunteers, after the specific training, should be encouraged to proactively participate in screening the suspicious infections and help in implementing proper quarantine measures by providing support services, such as driving patients to the mobile hospitals. All those activities should logistically be managed at the community level.

vii. The finding observed that there is distrust between the government and farmers. Farmers do not trust the government on the issue of COVID-19 pandemic. Some farmers still do not believe that there is even COVID-19. Therefore, it is important that the government should show transparent and accountable leadership so as to get full farmers to support in implementing strategies.

\section{ACKNOWLEDGMENTS}

The author is very grateful to the field volunteers of Centre for Building Farmers Capacity to Climate Change (CBFCCC); a rural-based Not-for-Profit Organization committed to the attainment of United Nations Agenda2030 goals no: 2, 12, 13 and 15 and Africa Agenda 2063 through partnership for goals (17). The $\boldsymbol{C B F C C C}$ filed volunteers helped in visiting the sampled farmers in their remote rice farms for evidence-based data collection even with restriction of movement in the country. Additionally, special thanks to the local rice farmers in the study area who provided the data for the study even amid hunger, lost of farm yield as a result of the COVID-19 pandemic. Thanks to all those involved in data entry, data cleaning, data coding, and analysis. We cannot thank you all enough.

\section{AREAS FOR FURTHER STUDY}

Constraints on restrictions of movement due to COVID-19 pandemic, the poor transportation network in rural areas, time and limited resources of the researcher forced to select only 504 rural-based rice farmers for the study across the Southeast States. Hence results are largely applicable to other areas of Nigeria not selected. Additionally, the questionnaire and personal interview method of data collection require the respondents to recall from their memories about their socio-economic variables, income, government support, COVID-19 precautionary measures and perceived effect of COVID-19 pandemic in rice farming amongst others. Most rural farmers do not keep farm records hence, the findings may be subject to memory lapses of the respondents.

Therefore, the author and further studies may attempt to link farmers perceived effect of COVID-19 pandemic in rice farming with the quantitative measurement of farm harvest, farm output per hectare, farm sales, farm income and other associated production variables. This is to evaluate the actual impact (before and after) of the pandemic in rice farming with a view of checking if farmers' perception were right. For instance, farmers may perceive there is a significant decrease in yield per hectare due to COVID-19 pandemic but the actual measurement may say otherwise and vice versa. This further study (impact) may require monitoring one or more rice farming seasons to systematically and logically evaluate.

\section{FUNDING}

No external funding was received for this research. 


\section{CONFLICTS OF INTEREST}

The author declares no conflict of interest

\section{REFERENCES}

[1] World Health Organization (WHO) (2020a). Infection prevention and control during health care when COVID19 is suspected https:/www.who.int/publications-detail/infection-prevention-and-control-during-healthcare-when-novel-coronavirus-(ncov)- infection-is-suspected-20200125

[2] Wang, H.; Wang, Z.b., Dong, Y., Chang, R., Xu, C., Yu, X., Zhang, S., Tsamlag, L., Shang, M., Huang, J., Wang, Y., Xu, G.; Shen, T., Zhang, X., Cai, Y. (2020). Phaseadjusted estimation of the number of Coronavirus Disease 2019 cases in Wuhan, China. Cell Discovery 6(1): Article number 10;Pp:2-8

[3] Yang J, Zheng Y, Gou X Ke.P, Zhaofeng. C, Qinghong. G, Rui. J, Haojia. W, Yuping. W, Yongning. Z (2020). Prevalence of comorbidities in the novel Wuhan coronavirus (COVID-19) infection: a systematic review and meta-analysis. Int J Infect Dis 2020; published online March 12. DOI:10.1016/j.ijid.2020.03.017; Pp:91-95

[4] African Centre for Disease Control (ACDC). (2020). COVID-19 Scientific and Public Health Policy Update1 - (31 July 2020). https://africacdc.org/download/covid-19-scientific-and-public-health-policy-update-31july-2020/\#

[5] Nigeria Centre for Disease Control (NCDC) (2020). "Covid-19 Page". Nigeria Centre for Disease Control.' https://covid19.ncdc.gov.ng/Retrieved 01 August, 2020.

[6] Akande T. (2020). An Overview of The Nigerian Rice Economy; Agriculture and Rural Development Department The Nigerian Institute of Social and Economic Research (NISER). 2020. Available from: https://unep.ch/ etb/etp/events/Agriculture/nigeria.pdf

[7] Food and Agricultural Organisation (FAO). The State of Food and Agriculture; 2010-2019. Rome: FAO; 2020. p. 2020

[8] Esiobu, N.S, Onubuogu, G.C; Njoku, S.M and Nwachukwu, B.C (2020). Sustainability and Determinate of Farmers' Mitigation Strategies to Greenhouse Gases (GHGs) Emission in Rice Agric-Food System in Nigeria; IntechOpen; DOI: http://dx.doi.org/10.5772/intechopen.93188; Vol. 9(6);Pp:01-16

[9] Ojo, O.T, Ogundeji A.A, Babu S.C, and Alimi T. (2020). Estimating financing gaps in rice production in Southwestern Nigeria. 2020;9:12. DOI: 10.1186/ s40008-020-0190-y

[10] Esiobu, N.S and Onubuogu, G.C. (2014). Trend, perceptions and adaptation options of arable crop farmers to climate change in Imo State, Nigeria; a multinomial logit approach. World Science Journal. 2014;5(9):12-24

[11] National Bureau of Statistics (NBS). (2007) National Bureau of Statistics Official Gazette (FGP 71/52007/2,500(OL24)): Legal Notice on Publication of the Details of the Breakdown of the National and State Provisional Totals, 2006 Census. 2007. Available from: www.nigerianstat.gov.ng [Accessed: 28 February 2016]

[12] Nigeria Population Commission (NPC) (2006). Nigeria Federal Government Initiative of individual head count by gender. Spread, State by State. MOFINEWS. 2006;6(3):01-32

[13] Nigerian Meteorological Agency (NiMET) (2020). Drought and Flood Monitoring in South East Bulletin. 2020. Available from: www.nimet.gov.ng [Accessed: 31 July 2020]

[14] Kushal, K.B. (2020). Analysis of greenhouse gas (methane and nitrous oxide) emission and global warming potential from rice fields: With reference to biological mitigation of climate change. Journal of Earth Sciences \& Environmental Studies. 2018;3(2):395-407

[15] National Bureau of Statistics and Federal Ministry of Agriculture and Rural Development (NBS/FMARD) (2016). Collaborative survey on national agricultural sample survey 2014/2015 Draft Report. Abuja, Nigeria: NBS. Press.

[16] Central Bank of Nigeria/Business day Nigeria (2020) (CBN/BD). Insecurity and poverty crisis in South East: Evidence of leadership failure; https://businessday.ng/opinion/article/insecurity-and-poverty-crisis-in-southeast-evidence-of-leadershipfailure/\#: :text=Following\%20Enugu\%20is\%20Abia\%20with,are\%20classified\%20as\%20very\%20poor.

[17] Kwadwo, A, Catherine, A, Paul, T, Kwaw, A and Mekonnen, A (2010). HIV and AIDS and farm labor productivity: A review of recent evidence in Africa; Journal of Development and Agricultural Economics Vol. 2(12), pp. 406-415

[18] Von Braun J, Hill RV and Pandya-Lorch R (2009). The poorest and hungry: a synthesis of analyses and actions. In von Braun J, Hill RV, PandyaLorch R (eds.). The Poorest and Hungry: Assessments, Analyses and Actions, Washington, D.C.: International Food Policy Research Institute, pp. 421-438.

[19] Esiobu N.S and Onubuogu G.C (2018). Determinant of risk-smart options among farming households in agricultural risk management in Imo State, Nigeria; (a multinomial logit model approach). Journal of Environment Protection and Sustainable Development. 2018;3(10):20-39

[20] Ngonidzashe, C, Laura A, Maria K, Sandra, L, Fernando C1, Manabu I, Ana M, Deissy M , Eduardo G, Santiago J, Carlos F.T, Miguel A, Myriam G, Ivan A, Sara H, Ditmar B.K, Gonzalo Z, Jose T, Pilar I, 
Silvana T, Gabriel L, Walkyria B. S, Aldo N and Cimelio B (2018). Sustainable and Low Greenhouse Gas Emitting Rice Production in Latin America and the Caribbean: A Review on the Transition from Ideality to Reality; Sustainability 2018, 10,671

[21] Esiobu, N. S (2018). Relative Efficiencies of Resource Use Among Cassava Farmers in Imo State, Nigeria; An M.Sc Thesis Submitted To The Department Of Agricultural Economics, Extension And Rural Development, Faculty Of Agriculture And Veterinary Medicine; Imo State University, Owerri, Nigeria

[22] Onubuogu, G.C and Esiobu N.S (2020). Determinants of allocative (pricing) efficiency of cassava farms in Imo State, Nigeria. Journal of Agriculture and Food Sciences. 2020;17(2):86-99. Available from: https://www.ajol.info/index.php/ jafs/article/view/194543

[23] George, A and A. Stylianou (2018). Evaluation of the Radio as an Agricultural Information Source in Rural Areas, Journal of Agricultural \& Food Information, 19:4, 362-376, DOI: 10.1080/10496505.2017.1401480

[24] Centre for Disease Control and Prevention (2020).Take steps to care for yourself and help protect others in your home and community. https://www.cdc.gov/handwashing/when-how-handwashing.html; accessed online 02, August, 2020

[24] International Monetary Fund (IMF) (2020). "World economic outlook, April 2020: the Great Lockdown". Available at https://www.imf.org/en/Publications/WEO/Issues/2020/04/14/weo-april-2020.

[25] Economic Commission for Africa (ECA) (2020). "COVID-19 in Africa: protecting lives and economies". Available at www.uneca.org/publications/covid-19-africa-protecting-lives-and-economies

[26] African Development Bank (AfDB) (2020) "African economic outlook 2020 amid COVID-19: supplement"

[27]United Nations (UN) (2020). "Policy brief: impact of COVID-19 in Africa". Available at https://www.uneca.org/sites/default/files/PublicationFiles/sg_policy_brief_on_covid19_impact_on_africa_ may_2020.pdf

[28] World Health Organization (WHO) (2020b). "WHO Director General's opening remarks at the media briefing on COVID-19". Available at https://www.who.int/dg/speeches/detail/who-director-general-sopening-remarks-at-the-media-briefing-on-covid19---11-march-2020.

[29] International Crops Research Institute for the Semi-Arid Tropics (ICRISAT). (2020). What African farmers and processors say about the COVID-19 pandemic and lockdowns; https://reliefweb.int/report/world/whatafrican-farmers-and-processors-say-about-covid-19-pandemic-and-lockdowns; assessed 3rd August, 2020

[30] International Food Policy Research Institute (IFPRI) (2020). Poverty and food insecurity could grow dramatically as COVID-19 spreads; https:/www.ifpri.org/blog/poverty-and-food-insecurity-could-growdramatically-covid-19-spreads; assessed 3rd August, 2020

[31]PricewaterhouseCoopers (Pwc) (2020). Responding to the impact of agriculture and food security https://www.pwc.com/ng/en/assets/pdf/impact-covid19-food-security-nigeria.pdf; assessed June, 2020

[32] Organisation for Economic Co-operation and Development (OECD) (2020). Trust in Government; https://www.oecd.org/gov/trust-in-government.htm; accessed 05 August, 2020 